\title{
Short stature due to partial GHR deficiency
}

INSERM

\section{Source}

INSERM. (1999). Orphanet: an online rare disease and orphan drug data base. Short stature due to partial GHR deficiency. ORPHA:314802

Short stature due to partial GHR deficiency is a rare, genetic, endocrine disease characterized by idiopathic short stature due to diminished GHR function (decreased lig and binding or reduced availability of receptor), thus resulting in partial insensitivity to growth hormone. 